\title{
Pulmonary Hypertension in Predialysis Chronic Kidney Disease: Frequency and Potential Mechanisms
}

\author{
MOHAMMED A. SOBH, M.D.*; AMAL M. ABDULAAL, M.D.**; SOHEIR M. KASEM, M.D.*; \\ MARWA K. ABDO, M.D.* and HANAA M. RIAD, M.Sc.* \\ The Departments of Internal Medicine* and Clinical Pathology**, Faculty of Medicine, Assiut University
}

\begin{abstract}
Background: Pulmonary arterial hypertension $(\mathrm{PH})$ and Chronic Kidney Disease (CKD) both profoundly affect patient outcomes, whether as primary disease states or as comorbid conditions. $\mathrm{PH}$ is a common comorbidity in $\mathrm{CKD}$ and vice versa. $\mathrm{PH}$ is an independent predictor of mortality in such patients. In a recent review, the prevalence of PHT in ESRD patients was reported to be around $40-50 \%$ however, the epidemiological data for this disorder in earlier stages of Chronic Kidney Disease (CKD) and the risk factors associated with its presence are scarce.
\end{abstract}

Aim: To evaluate the frequency of pulmonary hypertension among chronic kidney disease nondialysis dependent patients and to compare clinical and metabolic variables among those patients with the control group to search for possible mechanisms.

Subjects and Methods: 40 CKD patients (55\% men, $45 \%$ women; mean age, $42.9 \pm 15.13$ years) with. According to the magnitude of Glomerular Filtration Rate (GFR) decrease, the CKD patients have divided into 3 groups: (1) 2 patients with a GFR of $89-60 \mathrm{ml} / \mathrm{min}$; (2) 6 with a GFR of $59-45 \mathrm{ml} / \mathrm{min}$; (3) 32 with a GFR of $44-15 \mathrm{ml} / \mathrm{min}$. A control group consisted of 40 individuals with preserved kidney function (a GFR of $>90 \mathrm{ml} / \mathrm{min}$ ). Physical examination and echocardiography were performed in all the patients. The serum concentrations of homocysteine and serum PTH were determined.

Results: PH was detected in $20(50 \%)$ of the 40 patients with CKD. As CKD progressed, the frequency of pulmonary hypertension in Groups 1, 2, and 3 increased, amounting to $18.2 \%, 24.2 \%$, and $35 \%$, respectively.

Conclusion: This study demonstrated a high frequency of pulmonary hypertension among patients with CKD without dialysis.

The frequency was highest among patients especially those with older age higher, serum creatinine phosphorus creactive protein parathyroid hormone and homocysteine; lower hemoglobin, lower EF\% which all positively correlated with PASP and may be involved in the pathogenesis of pulmonary hypertension. Early detection of pulmonary hypertension is important in order to avoid the serious consequences of the

Correspondence to: Dr. Mohammed A. Sobh, The Department of Internal Medicine, Faculty of Medicine, Assiut University disease, also managing these potential mechanisms will result in areduction in the occurrence of pulmonary hypertension and thus reducing the incidence of the cardiovascular complications which are considered as one of the most important causes of death in the group of patients.

Key Words: Pulmonary hypertension - Chronic kidney disease - Urea-Creatinine - Echocardiography - Homocysteine - Parathyroid hormone.

\section{Introduction}

PULMONARY Hypertension (PH), a cardiovascular disorder characterized by elevated Pulmonary Artery Pressure (PAP), was found to be an unrecognized threat in a considerable proportion of patients with End-Stage Renal Disease (ESRD) [1].

In recent years, Pulmonary Hypertension $(\mathrm{PH})$ in Chronic Kidney Disease (CKD) patients is gaining interest because of its apparent high prevalence and its significant role in the outcome, principally in patients undergoing Hemodialysis (HD) [2]. This condition usually remains asymptomatic and sometimes is misdiagnosed over a period of time until right ventricular dysfunction begins to manifest by worsening fatigue, dyspnea and syncope [3] .

PH might be induced and/or aggravated by left ventricular disorders and risk factors typical of $\mathrm{CKD}$, including volume overload, arteriovenous fistula, sleep-disordered breathing, exposure to dialysis membranes, endothelial dysfunction, vascular calcification and stiffening, and severe anemia [4], oxidative stress and alteration of vasoactive mediators such as nitric oxide and endothelin-1 [5].

Therefore, this study was conducted to show the frequency of pulmonary hypertension in various CKD non dialysis dependent stages with the po- 
tential mechanisms that can lead to pulmonary hypertension in this population group.

Additionally a correlation between secondary hyperparathyroidism and $\mathrm{PH}$ have been reported, $\mathrm{PH}$ induced by increased parathyroid hormone associated with vascular calcification have been reported in CKD [6]

It is believed that hyperhomocysteinemia may cause changes in vascular endothelium, mainly mediated by the toxic effect of oxidized forms of this amino acid [7].

The evaluation of plasma homocysteine levels has been reported as a biomarker for endothelial dysfunction, linking its increase to severe diseases with endothelial injuries, such as Pulmonary Hypertension (PH) [8] . This is characterized by pulmonary arterial hypertension, and may reflect in dysfunction and right ventricular heart failure [9]

\section{Patients and Methods}

This study was conducted in Faculty of Medicine, Assuit University Hospital from Feb. 2016 August 2016.

It is an observational case-control study occurred in outpatient nephrology and internal medicine clinics included 80 candidates, 40 patients with different stages of pre-dialysis chronic kidney disease and 40 healthy volunteers based on exclusion and inclusion criteria where all patients with chronic kidney diseases non dialysis dependent and above or equal to 18 years were included but smokers, cardiovascular (coronary artery diseases and valvular heart diseases) pulmonary diseases (chronic obstructive lung diseases, chest wall or parenchymal lung diseases).

Which leads to pulmonary hypertension, also connective tissue diseases and patients with liver diseases were excluded.

Once all the criteria were satisfied, a written informed consent was taken and the patient was included in the study. A detailed history and physical examination of every patient including age, sex, duration of illness, etiology of chronic kidney disease, type of treatment received, associated comorbidity as diabetes and hypertension. Each patient underwent routine investigations like complete haemogram, serum electrolytes $(\mathrm{Ca}, \mathrm{PO} 4)$, renal function tests (BUN, serum creatinine), parathyroid hormone and homocysteine assays.
The laboratory assays were done by the following methods:

- Complete blood picture: By Cell Dyn 3700 Automated blood cell counter.

- Serum urea, creatinine, calcium and phosphorus: Cobas Integra 400-Plus clinical chemistry analyzer.

- Plasma parathyroid hormone level: By Sandwich chemiluminescence immunoassay using Maglumi 2000 Plus autoanalyzer (the kit supplied by Shenzhen New Industries, China, Catalog number 130211001M).

- Plasma homocysteine level: By ELISA technique using SinoGeneClon Kit, China (Catalog number SG-10387).

Test principle: Purified Human Homocysteine (HCY) coat the microtiter plate making solid phase antibody. HCY in the samples added to the wells combine HCY antibody with labeled HRP to form antibody-antigen-enzyme complex. After washing, TMB substrate was added, which become blue at HRP enzyme catalyzed reaction. The reaction was terminated by the addition of a stop solution and the color change was measured at a wave length of $450 \mathrm{~nm}$. The conc- ntration of HCY in the samples is then determined by comparing the optical density of the samples to the standard curve.

\section{Transthoracic Doppler echocardiography:}

Every patient had Undergone a complete twodimensional and Doppler echocardiography study, Echo-Doppler studies can provide an estimate of the PASP, a surrogate of mean pulmonary artery pressure, which is calculated on the basis of the tricuspid regurgitation jet velocity. In the absence of pulmonary stenosis, Right Ventricular Systolic Pressure (RVSP) approximates PASP by echoDoppler. PASP (assumed to be equal to RVSP) can be then estimated by calculating RVSP with the Bernoulli equation formula 4TRV (tricuspid regurgitant velocity) + RAP (right atrial pressure). Other echocardiographic measurements, including the right ventricular wall thickness and left atrial dimension and LV systolic and diastolic function, valvular apparatuses assessment and detection of any pericardial effusion all give additional, precious information for the diagnosis of PH by echoDoppler.

\section{Statistical analysis:}

The collected data will be analyzed statistically using IBM-SPSS Version 20. Continuous data will be expressed in form mean \pm SD and analyzed by using student $t$-test while nominal data will be 
expressed in form of frequency and proportion and compared by Chi-square test correlation of PASP with echocardiography findings and homocysteine level will be tested by using Pearson's correlation.

\section{Results}

Our results showed a highly statistically significant decrease in hemoglobin, and statistically significant increase in blood urea nitrogen, creatinine, phosphorous, C-reactive protein, parathyroid hormone, homocysteine between the studied chronic kidney diseases group and the control group, but no statistically differences were found between both groups with respect to age, BMI and serum calcium. A high prevalence of pulmonary hypertension (SPAP $>25 \mathrm{mmHg}$ ) was demonstrated among 20 patients in the chronic kidney diseases patients, which represent $50 \%$ in CKD group which had a highly statistically significant increase than in the control group where 4 patients only had pulmonary hypertension in the control group. An interesting result in our study showed also is that the more decrease in the glomerular filtration rate the more grade of pulmonary hypertension where the patients with grade IIII chronic kidney disease had moderate hypertension which represents $2.5 \%$ of the CKD patients. Our results also showed there is a negatively strong statistically significant correlation between PASP and hemoglobin level and ejection fraction where the decrease in the hemoglobin level and the decrease in the ejection fraction is strongly associated with the development of any grade of PASP.

Also, our results showed that there is a positively strong statistically significant correlation between PASP andLVDD, LVSD and LAD. In addition to the previous results, our study revealed a positive significant correlation between PASP and parathyroid hormone and PASP and homocysteine.

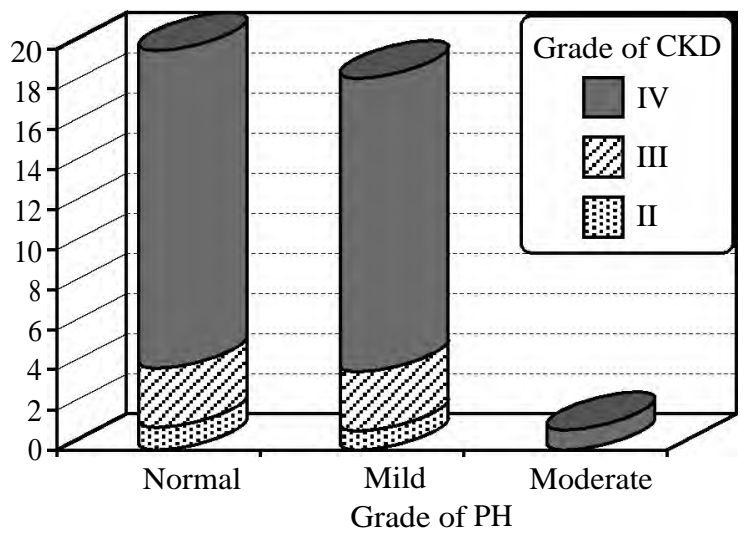

Fig. (1): Cross-tabulation between the grade of CKD and grade of $\mathrm{PH}$.

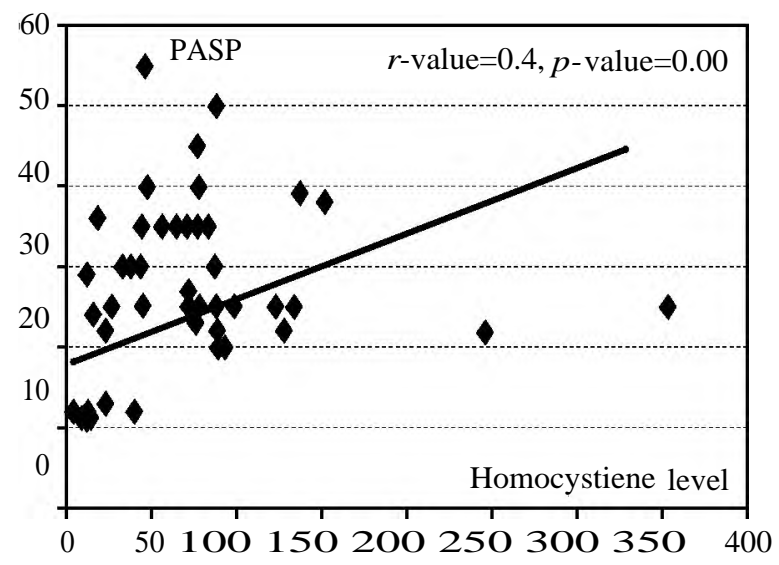

Fig. (2): Correlation of PASP with Homocystiene.

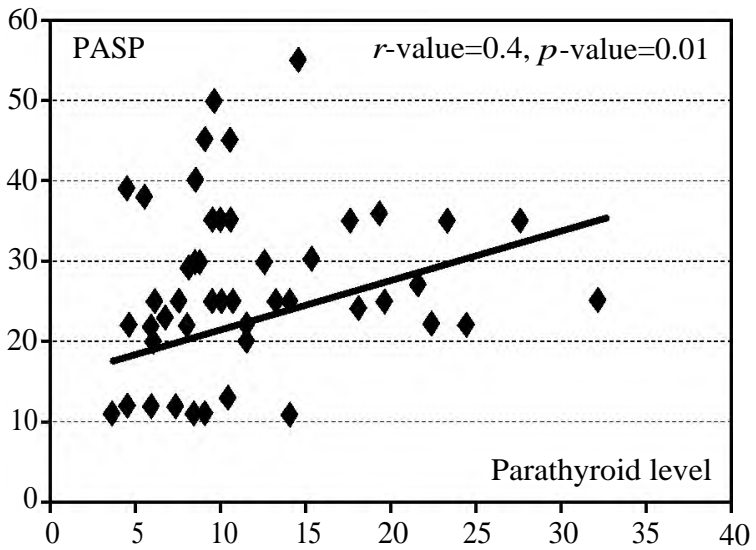

Fig. (3): Correlation of PASP with PTH.

Table (1): Baseline demographic and clinical parameters of the studied groups.

\begin{tabular}{|c|c|c|c|}
\hline Variables & $\begin{array}{l}\text { Study group } \\
(\mathrm{n}=40)\end{array}$ & $\begin{array}{l}\text { Control group } \\
\quad(n=40)\end{array}$ & $\begin{array}{c}p- \\
\text { value }\end{array}$ \\
\hline Age & $42.09 \pm 15.13$ & $35.13 \pm 8.45$ & 0.00 \\
\hline \multicolumn{4}{|l|}{ Sex: } \\
\hline Male & $22(55 \%)$ & $21(52.5 \%)$ & \multirow[t]{2}{*}{0.51} \\
\hline Female & $18(45 \%)$ & $19(47.5 \%)$ & \\
\hline$B M I:$ & $25.09 \pm 5.32$ & $24.69 \pm 2.96$ & 0.33 \\
\hline Under weight & $2(5 \%)$ & $2(5 \%)$ & \\
\hline Normal & $21(52.5 \%)$ & $19(47.5 \%)$ & \\
\hline Overweight & $17(42.5 \%)$ & $19(47.5 \%)$ & \\
\hline Hemoglobin level (g \%) & $9.13 \pm 2.27$ & $13.37 \pm 1.70$ & 0.00 \\
\hline Platelets count (X103) & $284.60 \pm 108.7$ & $277.30 \pm 50.19$ & 0.71 \\
\hline Urea $(\mathrm{m} / \mathrm{l})$ & $24.32 \pm 13.39$ & $5.05 \pm 2.05$ & 0.00 \\
\hline Creatinine ( mol/1) & $351.17 \pm 110.04$ & $83.87 \pm 31.43$ & 0.00 \\
\hline Calcium (mg\%) & $8.98 \pm 5.96$ & $10.22 \pm 0.76$ & 0.19 \\
\hline Phosphorus (mg\%) & $5.14 \pm 2.01$ & $1.97 \pm 0.84$ & 0.00 \\
\hline C-reactive protein & $7.28 \pm 2.09$ & $1 \pm 0.00$ & 0.00 \\
\hline Parathyroid level (pg/ml) & $84.12 \pm 12.93$ & $15.04 \pm 9.08$ & 0.02 \\
\hline Homocystiene (ml/l) & $13.38 \pm 3.04$ & $7.85 \pm 2.89$ & 0.01 \\
\hline
\end{tabular}


Table (2): Frequency of different grades of pulmonary hypertension in the studied population.

\begin{tabular}{llll}
\hline Variables & $\begin{array}{c}\text { Study group } \\
(\mathrm{n}=40)\end{array}$ & $\begin{array}{c}\text { Control group } \\
(\mathrm{n}=40)\end{array}$ & $\begin{array}{c}p \text { - } \\
\text { value }\end{array}$ \\
\hline PASP $(\mathrm{mmHg})$ & $30.35 \pm 8.66$ & $13.40 \pm 5.30$ & 0.00 \\
Grade of $\mathrm{PH}:$ & & & \\
$\quad$ Normal $(<25 \mathrm{mmHg})$ & $20(50 \%)$ & $36(90 \%)$ & 000 \\
Mild $(25-50 \mathrm{mmHg})$ & $19(47.5 \%)$ & $4(10 \%)$ & \\
Moderate $(50-70 \mathrm{mmHg})$ & $1(2.5 \%)$ & $0(0 \%)$ & \\
$\quad$ Severe $(>70 \mathrm{mmHg})$ & $0(0 \%)$ & $0(0 \%)$ & \\
\hline
\end{tabular}

Table (3): Correlation of PASP with hemoglobin, LVDD, LVSD, EF and LA.

\begin{tabular}{lcc}
\hline \hline Variables & Strength of association & $p$-value \\
\hline Hemoglobin & -0.60 & 0.00 \\
LVDD & 0.23 & 0.03 \\
LVSD & 0.21 & 0.01 \\
LAD & 0.63 & 0.00 \\
EF & -0.52 & 0.00 \\
\hline
\end{tabular}

\section{Discussion}

The decrease in kidney function may be a trigger for the development of PASP disturbance. The Doppler-estimated PASP increased inversely to renal function. In kidney disease, a series of complications appears eventually, such as anemia, endothelial dysfunction, LV dysfunction, and volume overload. Severe anemia, an established cardiovascular risk factor in $\mathrm{CKD}$, may extend its impact to pulmonary circulation [5]. In practice any condition which leads to shunt of the blood from the left side of the heart to the right side will lead eventually to increase in the cardiac output and though will lead to increase in the pulmonary blood flow and thus it will result in pulmonary hypertension [10]. Previous studies showed that pulmonary hypertension is avery common complication in chronic kidney diseases patients especially those who had reached end stage renal disease [11]

In the present study which is considered a new study which tries to detect the frequency, and the possible etiologies of pulmonary hypertension in predialysis patients as this topic is underestimated in many studies which give greater concern to those on haemodialysis.

The early detection of pulmonary hypertension and recognition of its causes may help to delay its occurrence and progression by good treatment as many causes may be preventable and treatable.

On the other hand, sever pulmonary hypertension may hinder or even leads to transplantation failure.
We found in our study that pulmonary hypertension occurred early in the disease even before the symptoms of CKD had been prominent but the severity of former correlates negatively with the eGFR.

There were multiple etieolgies of $\mathrm{PH}$ in the present study which will be discussed separately.

Decreased eGFR and hemoglobin level may increase pulmonary artery pressure due to volume overload and increased pulmonary blood flow due to anemia [12]

Also this result was nearly in agreement with those reported by Genctoy et al., [13] .

We observed that grade IV CKD had the highest frequency among our patients and grade I had the lowest frequency and this owing to that CKD is considered a silent disease in its early grades and has a non specific symptoms; added to low awareness of our patients and low socioeconomic status.

In present study, we found that; the patients group had a higher mean Pulmonary Artery Systolic Pressure (PASP)-compared to the control group $(30.35 \pm 8.66 \mathrm{mmHg}$ versus $13.40 \pm 5.30)$ with a statistically significant difference ( $p$-value $=0.00)$ and the prevalence of $\mathrm{PH}$ was $50 \%$ (20/40), in our patients. eGFR was calculated using the modification of diet in renal disease study equation.

The prevalence of $\mathrm{PH}$ was higher in patients with stage 3-4 CKD compared with stage 1-2 CKD.

As grade IV CKD had the highest frequency of $\mathrm{PH}$ as $15(46.87 \%)$ had a mild pulmonary hypertension and one patient $(3.1 \%)$ had a moderate degree of $\mathrm{PH}$, on the other hand, grade II CKD had the lowest frequency i.e one patient had mild degree of $\mathrm{PH}$.

This result was nearly in agreement with those reported by Yang and Bao., [5] PH prevalence reached $48.15 \%(13 / 27)$ in the GFR $<60 \mathrm{~mL} / \mathrm{min} /$ $1.73 \mathrm{~m}^{2}$ group, the GFR $\geq 60 \mathrm{~mL} / \mathrm{min} / 1.73 \mathrm{~m}^{2}$ group (with less renal injury) still has a prevalence of $23.76 \%, 24$ of 101 CKD patients.

Also, our results were nearly in agreement with those reported by Havlucu et al., [6] PSAP $>35$ $\mathrm{mmHg}$ was founded in $39.1 \%(9 / 23)$ of predialysis patients $(29.5 \pm 9.5 \mathrm{~mm} \mathrm{Hg})$.

The causes of pulmonary hypertension in the studied population was multifactorial, hyperparathyroidism, hyperhomocystenamia, endothelial 
dysfunction and inflammatory process as well as left ventricular dysfunction were recorded.

In our study that there was statistically significant correlation between PSAP and level of parathyroid hormone.

This was inaccordance with Ulrich et al., [14] who found a particularly striking elevation of the mean PTH serum levels in patients with PH.

Also, these results were nearly in agreement with those reported by Demir et al., [15] who was reported that hyperparathyroidism duo to low vitamin D levels was associated with increased pulmonary artery pressure.

But these results were not in agreement with those reported by Amin et al., [16] whose investigations of the parathyroid gland activity revealed no difference between patients with and without $\mathrm{PH}$, with regards to values of $\mathrm{PTH}$, but this study was done in patients with Chronic Renal Failure (CRF) receiving regular haemodialysis.

In our study, that there was statistically significant positive correlation between PSAP and level of homocysteine.

In our study, that there was statistically significant positive correlation between PSAP and level of homocysteine.

This result was nearly in agreement with those reported by Arroliga et al., [8]. There was a correlation between the Homocysteine levels and PH.

Volume overload, implicated in LV disorders and in the high venous return, and LV diastolic dysfunction, an alteration found in patients with CKD to increase pulmonary venous and arterial pressure [17], may together induce $\mathrm{PH}$ by increasing pulmonary blood flow and adversely affecting LV function.

In the present study, correlation between PASP and both LVDD and LVSD While EF had a negative significant correlation with PASP.

These results are in concordance with Yigla et al., [18], Havlucu et al., [6] and Abdallah et al., [19], and similar results reported by Beigi et al., [20], Fabbian et al., [21] andEmara et al., [22] reported an inverse correlation between PAP and ejection fraction.

High C-Reactive Protein (CRP) is independent risk of mortality in patients with Chronic Kidney Disease (CKD).
C-Reactive Protein (CRP) levels are elevated in patients with kidney disease [23] and are an independent predictors of cardiovascular mortality in this patient population [24]. CRP in particular, are independent predictors of the future risk of outcomes both in the general population and among patients with kidney disease.

In our study, although there was positive correlation between PASP and CRP but of no significant value as $p$-value was $>0.05$, and this may be due to small sample size of our patients.

This result was nearly in agreement with those reported byPereira et al., [25]

Lastly, the results of this study suggest that a significant proportion of pre-dialysis CKD patients showed functional abnormality in their pulmonary circulation. Apart from hyperhomocysteinemia, lower EF\%, secondary hyperparathyroidism, anemia, hyperphosphatemia, and CRP and inflammation may contribute to increasing PAP in patients with CKD.

\section{Study limitations:}

This study has certain limitations. The exclusion criteria used in our protocol resulted in a small study group, since the majority of patients with CKD had concomitant cardiac or pulmonary disease. The exclusion of patients with CKD with cardiac or pulmonary disease from the analysis was a methodological necessity. Moreover, PASP was measured by a non-invasive method, Doppler echocardiography, with-out obtaining direct invasive measurements (e.g. right heart catheterization). However, measurements of PASP by the applied Doppler echocardiographic method have been reported to have a good correlation with measurements obtained by invasive methods in some studies.

\section{References}

1- Di-LULLO L., FLOCCARI F., RIVERA R., BARBERA V., GRANATA A., et al.: Pulmonary Hypertension and Right Heart Failure in Chronic Kidney Disease: New Challenge for 21 st-Century Cardionephrologists. Cadiorenal. Med., 3: 96-103, 2013.

2- REQUE J., QUIROGA B., RUIZ C., VILLAVERDE M.T., VEGA A., ABAD S., PANIZO N. and LOPEZ-GOMEZ J.M.: Pulmonary hypertension is an independent predictor of cardiovascular events and mortality in hemo dialysis patients. Nephrology (Carlton). 21: 321-6, 2016.

3- HOEPER M.M., BOGAARD H.J., CONDLIFFE R. FRANTZ R., KHANNA D., KURZYNA M., et al.: Definitions and diagnosis of pulmonary hypertension. J. Am. Coll. Cardiol., 62 (25 suppl): D42-D50, 2013. 
4- KAWAR B., ELLAM T., JACKSON C. and KIELY D.G.: Pulmonary hypertension in renal disease: Epidemiology, potential mechanisms and implications. Am. J. Nephrol., 37: 281-90, 2013.

5- YANG Q.M., BAO X.R., TSAI M.K., KUO T.B. and YANG C.C.: Pulmonary hypertension in patients with stage 1-3 chronic kidney disease. Genet. Mol. Res., 13: pp. 5695-703, 2014.

6- HAVLUCU Y., KURSAT S., EKMEKCI C., CELIK P., SERTER S., BAYTURAN O. and DINC G.: Pulmonary hypertension in patients with chronic renal failure. Respiration, 74: 503-10, 2007.

7- AMORIM F.D., PALMEIRA A.C., GABRIELLA M.A., MÔNICA O.S., ALESSANDRA T.R. and CARLA C.M.: Bioquímicaclínica da atherosclerose provoked hyperhomocisteinemia. Revista Eletrônica de Farmácia, V. 8, N. 1, p. 36-59, 2011.

8- ARROLIGA A.C., SANDUR S., JACOBSEN D.W., TEWARI S., MUSTAFA M., MASCHA E.J. and ROBINSON K.: Association between hyperhomo-cysteinemia and primary pulmonary hypertension. J. Vasc. Access., 825-9, 2003.

9- BICHARA V.M., VENTURA H.O. and PERRONE S.V.: Hipertensiónpulmonar: La mirada del especialista. Insuficiencia Cardiaca, V. 6, N. 2, p. 65-79, 2011.

10- FARBER J. LOSCALZO:Pulmonary arterial hypertension, N. Engl. J. Med., 351: 1655-65, 2004.

11-ABDELWHAB S. ELSHINNAWY: Pulmonary hypertension in chronic renal failure patients, Am. J. Nephrol., 28: 990-7, 2008.

12- GENCTOY GULTEKIN, SERAP ARIKAN and OLCAY GEDIK: Secondary hyperparathyroidism is associated with pulmonary hypertension in older patients with chronic kidney disease and proteinuria, pp. 353-8, 2015.

13- NAKHOUL F., YIGLA M., GILMAN R., REISNER S.A. and ABASSI Z.: The pathogenesis of pulmonary hypertension in haemodialysis patients via arterio-venous access. Nephrol. Dial. Transplant., 20: 1686-169, 2005.

14- ULRICH S., HERSBERGER M., FISCHLER M., HUBER L.C., SENN O., TREDER U., SPEICH R. and SCHMID C.: Bone mineral density and secondary hyperparathyroidism in pulmonary hypertension. Open Respir. Med. J., 14 (3): 53-60, 2009.

15- DEMIR M., UYAN U., KEÇEOÇLU S. and DEMIR C.:
The relationship between vitamin D deficiency and pulmonary hypertension. Prague Med. Rep., 114 (3): 15461, 2013.

16- AMIN M., FAWZY A., HAMID M.A. and ELHENDY A.: Pulmonary hypertension in patients with chronic renal failure: Role of parathyroid hormone and pulmonary artery calcifications. Chest., 124: 2093-7, 2003.

17- TIENGO A., FADINI G.P. and AVOGARO A.: The metabolic syndrome, diabetes and lung dysfunction. Diabetes Metab., 34: 447-54, 2008.

18- YIGLA M., NAKHOUL F., SABAG A., TOV N., GOREVICH B., ABASSI Z. and REISNER S.A.: Pulmonary hypertension in patients with end-stage renal disease. Eur. Respir. Rev., 22: 526-34, 2003.

19- ABDALLAH E.A., WAKED E., METWALY A. and KHALEK A.A.: Role of arterio-venous shunt in the pathogenesis of pulmonary hypertension in patients with endstage renal disease. Kidney, 19: 239, 2010.

20- BEIGI A.A., SADEGHI A.M., KHOSRAVI A.R., KARAMI M. and MASOUDPOUR H.: Effects of the arteriovenous fistula on pulmonary artery pressure and cardiac output in patients with chronic renal failure. J. Vasc. Access., 10: 160-6, 2009.

21- FABBIAN F., CANTELLI S., MOLINO C., PALA M., LONGHINI C. and PORTALUPPI F.: Pulmonary hypertension in dialysis patients: A cross-sectional Italian study. International Journal of Nephrology. J. Am. Coll. Cardiol., 62 (Suppl D): D100-D108, 2011.

22- EMARA M.M., HABEB M.A., ALNAHAL A.A., ELSHAZLYD T.A., ALATAWIE F.O. and MASOUD A.S.: Prevalence of pulmonary hypertension in patients with CKD on and without dialysis. Egyptian Journal of Chest Diseases and Tuberculosis, 62: 761-8, 2013.

23- ARICI M. and WALLS J.: End-stage renal disease, atherosclerosis, and cardiovascular mortality: Is C-reactive protein the missing link? Kidney Int., 59, pp. 407-14, 2001.

24- WANNER C., ZIMMERMANN J., SCHWEDLER S. and METZGER T.: Inflammation and cardiovascular risk in dialysis patients Kidney Int., 61 (Suppl 80), pp. 99-102, 2002.

25- PEREIRA, SANTICA M. VANDANA M., et al.: Creactive protein and albumin as predictors of all-cause and cardiovascular mortality in chronic kidney disease. Am. J. Kidney Dis., 52: 39, 2005. 


\section{إرتفاع ضغط الشريان الرئوى فى مرضى الإعتلال الكلوى المزمن

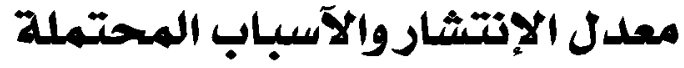

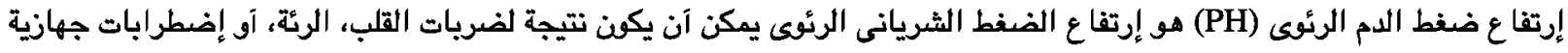

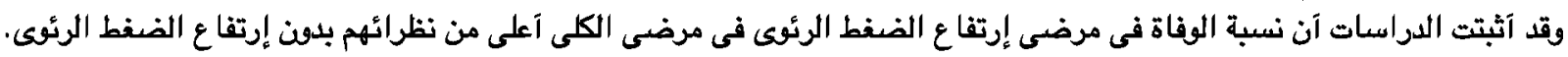

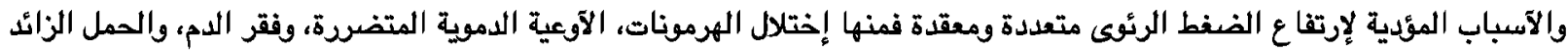

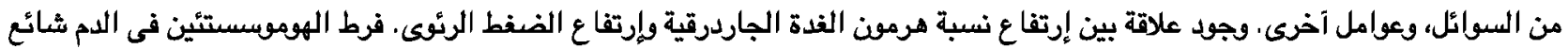
فى المرضى الذين يعانون من القصور الكلوى المزمن. حمض الآمينى هو من الآحماض الآمينية الكبريتية تشكلت خلال عملية التمثيل الغذائى للميشيونين. التمثيل الغذائى وترشيح الكلى يلعب دودا بارذا فى إزالة الحمض الآمينى من الدم. إن زيادة مستويات الحمض الآمينى فى البلازما تفضل حدوث الآمراض، مثل إحتشاء عضلة القلب الحاد، تخثر الدم، وتملب الشرايين وإرتفاع ضغط الدم الرئنى.

ويعتقد آن فرط الهوموسستئين فى الدم قد تسبب تغيرات فى بطانة الآوعية الدموية، وربط زيادة الحمض الآمينى فى البلازما وإختلال وظيفة

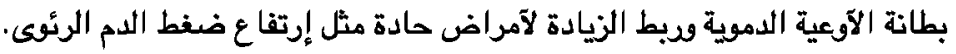
الهدف من الدراسة: التقييم مدى إنتشار ضغط الدم الرئوى الآساسى بين المرضى قبل مرحله الغسيل الكوىى. لمقارنة المتغيرات والتمثيل الغذائى بين المرضى مع ويدون إرتفاع الضغط الرئوى اللبحث عن الآسباب المرضية المحتملة. نتيجة البحث: في هذه الدراسة لتصديد الآسباب المرضية المحتملة المؤدية إلى إرتفاع الضغط الرئقى فى مرضى الإعتلال الكلىى المزمن

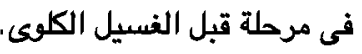
وقد شملت هذه الدراسة على • ع مريض يعانون من قصور كلوى بمراحله المختلفة، و.ع آصحاء لمقارنة المتغيرات والتمثيل الغذائى بين

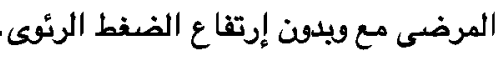
وقد وجدت الدراسة آن نسبة إرتفاع الضغط الرئوى سجلت (•٪) من المرضى الخاضعين اللدراسة لدينا فى مرحلة قبل الغسيل الكلوى

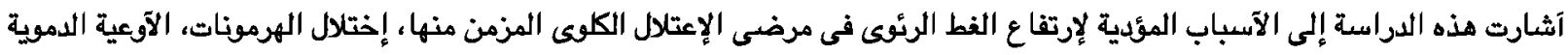

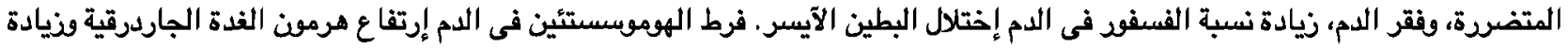
البرتين والإلتهاب على التوالى. 